\title{
FORMULASI PERBANDINGAN ASAM BASA SERBUK EFFERVESCENT DARI COKLAT BUBUK
}

\section{Ratio of Acid Base Formulation of Effervescent Powder from Cocoa Powder}

Inda Three Anova*, Wilsa Hermianti, dan Kamsina

Balai Riset dan Standardisasi Industri Padang

JI.Raya LIK no.23 Ulu Gadut Padang

*e-mail: indova99@gmail.com

Diterima: 5 September 2016, revisi akhir: 13 Desember 2016 dan disetujui untuk diterbitkan: 13 Desember 2016

\section{ABSTRAK}

Coklat dapat dibuat berbagai macam produk minuman coklat. Minuman coklat biasanya diminum dengan mencampur susu atau kopi dan diminum dengan air panas menjadi minuman penyegar. Coklat dapat dibuat menjadi minuman effervescent, minuman ini menghasilkan gelembung gas yang memberikan rasa enak. Adanya karbonat dapat memberikan rasa lain, sehingga tercipta diversifikasi rasa yang lebih menarik. Tujuan penelitian ini adalah untuk mendapatkan formulasi yang optimal dalam pembuatan serbuk minuman effervescent dari coklat bubuk dan variasi minuman dari coklat bubuk yang lebih beragam. Penelitian dilakukan dengan menggunakan metode perbandingan asam sitrat : asam tartarat $(A)$ dan asam : basa (B). Hasil penelitian menunjukkan bahwa perlakuan perbandingan asam dan asam basa berpengaruh pada nilai $\mathrm{pH}$, kandungan lembab, waktu alir, nilai kompressibilitas dan waktu larut. Perlakuan optimal didapat pada perbandingan asam sitrat : tartarat (1:2) dan perbandingan asam $20 \%$ : basa $25 \%$ yang mempunyai nilai $\mathrm{pH} 6,77$, kandungan lembab 1,3\%, waktu alir 6,19 g/detik, kompressibilitas 28,83 dan waktu larut 5,69 menit. Selain nilai kompressibilitas dan waktu larut secara keseluruhan memenuhi kriteria untuk minuman serbuk effervescent.

\section{Kata kunci: Coklat bubuk, effervescent, asam sitrat, asam tartarat, basa}

\begin{abstract}
Chocolate can be made various kinds of chocolate drink products. Chocolate drink is usually mix with milk or coffee and drink with hot water become a refreshing drink. Chocolate can be made into effervescent drinks, these drinks produce gas bubbles which gives good taste. The presence of carbonate can provide another taste, so as to create a more interesting flavor diversification. The purpose of this study was to get optimal formulation to make an effervescent cocoa powder and more variety of cocoa powder drinks. The study was conducted by using a comparison method of citric acid : tartatic acid $(A)$ and acid : base $(B)$. The results showed that treatment of acid ratio and acid-base had an effect on the $\mathrm{pH}$ value, moisture content, flow time, compressibility value, and soluble time. Optimal treatment was obtained in ratio of citric acid : tartaric acid (1:2) and ratio acid 20\% : base 25\% which had $\mathrm{pH}$ value 6.77 , moisture content $1.3 \%$, the flow time $6.19 \mathrm{~g} / \mathrm{sec}$, compressibility 28.83 , and soluble time 5.69 minutes. Except the compressibility value and soluble time, as a whole met criteria for effervescent powder drink.
\end{abstract}

Keywords: Cocoa powder, effervescent, citric acid, tartaric acid, base

\section{PENDAHULUAN}

Hasil-hasil perkebunan Indonesia sangat banyak jumlahnya dan dapat mendatangkan devisa. Dewasa ini hasil perkebunan yang sangat menonjol dan menjadi prioritas untuk dikembangkan adalah coklat. Indonesia merupakan negara produsen kakao terbesar ke tiga dunia setelah Pantai Gading dan Ghana dengan produksi biji kakao kering pada 
tahun 2011 mencapai 712.231 ton (Direktorat Jendral Perkebunan, 2013),

Coklat dapat dibuat berbagai macam produk makanan atau minuman, antara lain coklat batang, coklat oles, coklat topping, coklat blok, coklat bubuk, dan tak kalah populernya yaitu minuman coklat. Minuman coklat biasanya dibuat dari coklat bubuk diminum dengan mencampurnya dengan susu atau kopi dan diminum dengan air panas menjadi minuman penyegar (Supriyanto et al., 2013).

Cokelat bubuk cukup diminati para konsumen karena sifatnya yang praktis untuk dikonsumsi, baik dikonsumsi langsung sebagai minuman panas maupun dingin, serta bisa digunakan sebagai bahan campuran dalam pembuatan berbagai jenis panganan lainnya. Cokelat bubuk yang biasa dibuat minuman cokelat atau campuran bagi makanan dan minuman diketahui memiliki kadar polifenol yang tinggi terutama dari golongan flavanol. Flavanol dikenal sebagai senyawa antioksidan alami dapat berperan sebagai penangkal radikal bebas. Bahkan dalam beberapa hasil penelitian cokelat bubuk mempunyai kapasitas antioksidan yang lebih tinggi dibandingkan dengan teh hijau, anggur dan buah-buahan lain yang telah dikenal sebelumnya (Supriyanto et al., 2013).

Menyiapkan minuman cokelat sebelum diminum cukup memakan waktu, sebelum siap disajikan harus ditambah gula, terkadang susu krim atau creamer terlebih dahulu untuk menutupi rasa pahitnya. Selain itu berdasar pengalaman diperlukan pengadukan cukup lama. Untuk mendorong lebih banyak konsumsi produk cokelat terutama dalam bentuk minuman cokelat perlu dilakukan diversifikasi produk yang lebih praktis, dengan sensasi rasa baru yang lebih menarik, antara lain dalam bentuk effervescent. Untuk menyajikan minuman cokelat dalam bentuk effervescent cokelat cukup di jatuhkan atau dimasukkan dalam air panas atau dingin tanpa perlu dilakukan pengadukan, produk tersebut akan cepat larut dan siap diminum (Supriyanto et al., 2013).

Effervescent merupakan bentuk sediaan yang menghasilkan gelembung gas sebagai hasil dari reaksi kimia dalam larutan. Keunggulan dari sediaan effervescent adalah rasanya enak karena adanya karbonat yang membantu memperbaiki rasa, lebih menarik dalam penyajian, penyiapan larutan dalam seketika dan mengandung dosis obat yang tepat sehingga lebih praktis serta daya simpan tablet yang relatif lebih lama dibanding dalam bentuk larutan. Effervescent merupakan rekasi antara asam dan basa yang mengasilkan gas karbondioksida. Effervescent dibuat pada ruangan yang mempunyai kelembaban rendah, yaitu $10 \%$ dan suhu $65-75^{\circ} \mathrm{F}$ (Lee, 2010).

Pembuatan serbuk effervescent ada dua cara yaitu pertama metode kering atau peleburan, dalam metode ini satu molekul air yang ada pada setiap molekul asam sitrat bertindak sebagai unsur penentu bagi pencampuran serbuk. Asam sitrat dijadikan serbuk, baru dicampurkan dengan serbuk lainnya (setelah disaring melewati ayakan 60 mesh) untuk meratanya pencampuran. Pengadukan dilakukan secara cepat dan lebih baik dalam lingkungan yang kelembabannya rendah untuk mencegah terhisapnya uap air dari udara oleh bahan kimia sehingga reaksi kimia terjadi lebih dini (Anam et al., 2013). Setelah pengadukan serbuk diletakkan di atas nampan dan dioven pada suhu $33-40^{\circ} \mathrm{C}$, dibolak balik menggunakan spatel tahan asam. Bahan pangan berasam tinggi atau sedang bersifat sangat korosif terhadap baja, sehingga digunakan alat yang tahan asam. Selanjutnya saat pemanasan berlangsung serbuk menjadi seperti spon dan setelah mencapai kepadatan yang tepat (seperti adonan roti), serbuk dikeluarkan dari oven dan digerus melalui suatu ayakan untuk membuat serbuk sesuai dengan yang diinginkan. Metode peleburan ini digunakan dalam mengolah hampir semua serbuk effervescent yang diperdagangkan. Metode yang kedua adalah metode basah, berbeda dengan metode kering unsur penentu tidak perlu air kristal asam sitrat, tetapi boleh ditambahkan air, yang digunakan untuk membuat adonan bahan lunak dan larutan untuk membuat serbuk (Novidiyanto dan Setyowati, 2008).

Kelarutan merupakan parameter yang perlu diamati saat membuat formula dan memilih bahan baku untuk 
effervescent. Jika bahan baku yang digunakan tidak larut dalam air reaksi effervescent tidak akan terjadi dan granula effervescent tidak dapat larut sempurna secara cepat. Effervescent yang baik dapat larut dengan cepat dalam waktu 1 - 2 menit (Linberg, 1992). Sedangkan menurut United States Pharmacopedia (2009) tablet effervescent harus sudah hancur dan larut sempurna dalam waktu 2 menit. Effervescent untuk keperluan makanan dan minuman belum ada persyaratannya, namun waktu larut yang mendekati 2 menit mestinya akan lebih baik. Kecepatan waktu larut effervescent selain dipengaruhi oleh kadar air (Lieberman, 1989), juga sangat dipengaruhi oleh jumlah dan perbandingan antara asam dan basa yang digunakan (Ansel, 1989).

Produk effervescent sampai sekarang masih banyak digunakan oleh kalangan farmasi untuk obat-obatan. Penelitian ini bertujuan untuk mempelajari kemungkinan pembuatan effervescent dari cokelat bubuk, menentukan jumlah campuran asam dan basa yang diperlukan dan menentukan perbandingan antara jumlah asam dan jumlah basa yang digunakan untuk membuat tablet effervescent yang baik dan disukai panelis.

\section{METODOLOGI PENELITIAN}

Bahan dasar yang digunakan dalam pembuatan serbuk effervescent cokelat adalah cokelat bubuk komersil yang diperoleh dari industri coklat yang berasal dari Padang Pariaman Sumatera Barat. Sedangkan bahan kimia yang digunakan adalah asam sitrat, asam tartarat, natrium bikarbonat, natrium karbonat, gula rendah kalori, dan kemasan alumunium foil.

Peralatan yang digunakan meliputi; alat ekstraksi skala laboratorium, saringan, spatula, corong pemisah, mortar, magnetic stirer, water bath, timbangan, alat-alat gelas, oven serta peralatan pengujian. Proses penelitian dilakukan dengan tahapan berikut.

\section{Proses Ekstraksi Coklat Bubuk}

Tahap pertama yang dilakukan adalah menimbang 100 gram cokelat bubuk dan diekstraksi dengan $500 \mathrm{ml}$ air hangat bersuhu $80^{\circ} \mathrm{C}$ dengan perbandingan cokelat bubuk : air hangat $=$ 1:5, kemudian diaduk dengan magnetic stirer selama 10 menit. Kemudian dilakukan penyaringan dengan menggunakan kertas saring, ekstrak yang didapatkan ditambahkan dekstrin (25\%) sebagai bahan pengisi dan dikeringkan diatas water bath suhu $50^{\circ} \mathrm{C}$, sehingga didapatkan ekstrak dalam bentuk kering, lalu dihaluskan dan diayak dengan ukuran 80 mesh.

\section{Pembuatan Serbuk Effervescent}

Ekstrak coklat dalam bentuk kering sesuai komposisi serbuk effervescent di bagi menjadi dua bagian. Bagian pertama di tambahkan pemanis dan perbandingan asam sitrat dan tartarat sesuai perlakuan (A) (1:1,5 dan 1:2) dengan jumlah perbandingan bagian asam sesuai dengan perlakuan, perbandingan asam basa (B) (25\%:20\%, 20\%:25\%, dan15\%:30\%). Bagian kedua ekstrak coklat bubuk ditambahkan bagian basa sesuai dengan perlakuan dan CMC 1,5\%. Kedua bagian diaduk dengan spatula secara terpisah. Setelah itu dilakukan pencampuran sampai homogen dan pengayakan sehingga didapatkan serbuk effervescent coklat. Kemudian serbuk tersebut di masukan ke dalam oven suhu $40^{\circ} \mathrm{C}$ selama 1 jam, di letakkan dalam desikator selama 15 menit, dikemas menggunakan alumunium foil dan diseal. Pemakaian pemanis yang rendah kalori dimaksudkan agar minuman ini aman dan dapat dikonsumsi bagi konsumen yang menderita penyakit gula.

\section{HASIL DAN PEMBAHASAN Analisis Bahan Baku Coklat Bubuk}

Hasil analisis bahan baku coklat bubuk dan gula rendah kalori seperti pada Tabel 1.

Tabel 1. Analisa bahan baku

\begin{tabular}{clcc} 
No. & Bahan & Kadar Air (\%) & pH \\
\hline 1 & Coklat bubuk & $38,07 \%$ & 6,70 \\
2 & Gula rendah kalori & $0,12 \%$ & 5,60 \\
\hline
\end{tabular}

Dari Tabel 1 dapat dilihat bahwa nilai kadar air dan $\mathrm{pH}$ dari masing-masing bahan yang digunakan pada pembuatan 
serbuk effervescent, untuk coklat bubuk mempunyai kadar air yang tinggi dan tidak memenuhi persyaratan dari coklat bubuk (BSN, 2013), sehingga sebelum digunakan untuk pembuatan serbuk effervescent harus dikeringkan lagi terlebih dahulu sampai memenuhi yaitu sekitar $5 \%$. Sedangkan untuk kadar air dari gula yang digunakan telah memenuhi kadar air dari gula (BSN, 2010). Untuk nilai pH mendekati netral yang berkisar diantara 67.

\section{Analisis pH Serbuk Effervescent}

Uji $\mathrm{pH}$ perlu dilakukan karena jika larutan effervescent yang terbentuk terlalu asam dapat mengiritasi lambung, sedangkan jika terlalu basa menimbulkan rasa pahit dan tidak enak. $\mathrm{pH}$ Larutan effervescent dikatakan baik jika $\mathrm{pH}$ mendekati netral yaitu 6-7. Hasil uji $\mathrm{pH}$ dapat dilihat pada Gambar 1. Berdasarkan hasil pengujian $\mathrm{pH}$ larutan effervescent pada Gambar 1, untuk produk effervescent $\mathrm{pH}$ berkisar antara 4,44-7,58. Untuk perlakuan A2B2 (perbandingan asam sitrat : tartarat 1:2 dan perbandingan asam basa 20\%:25\%) dan perlakuan A1B1 (perbandingan asam sitrat : tartarat 1:1,2 dan perbandingan asam basa 25\%:20\%) memiliki $\mathrm{pH}$ larutan yang asam, disebabkan konsentrasi komponen asam lebih banyak dari komponen basa. sedangkan untuk perlakuan A1B2 (perbandingan asam sitrat : tartarat 1:1,5 dan perbandingan asam basa 20\%:25\%), perlakuan A1B3 (perbandingan asam sitrat : tartarat 1:1,5 dengan perbandingan asam basa 15\%:30\%), perlakuan A2B1 (perbandingan asam sitrat : tartarat 1:2 dan perbandingan asam basa 25\%:20\%), serta perlakuan A2B3 (perbandingan asam sitrat : tartarat 1:2 dengan perbandingan asam basa 15\%:30\%) mempunyai $\mathrm{pH}$ larutan cenderung netral. Hal ini disebabkan konsentrasi komponen basa lebih banyak atau berimbang dari komponen asam.

Hasil analisis $\mathrm{pH}$ memperlihatkan bahwa perbandingan pemakaian jenis asam dan perbedaan konsentrasi asam basa berpengaruh nyata pada nilai $\mathrm{pH}$ serbuk effervescent coklat. Hal ini disebabkan terjadinya peningkatan jumlah ion $\mathrm{H}^{+}$pada larutan yang berasal dari asam yang ditambahkan. Menurut Sandrasari dan Abidin (2012) faktor lain yang mempengaruhi perbedaan nilai $\mathrm{pH}$ dari perlakuan ini adalah terbentuknya $\mathrm{CO}_{2}$ pada saat reaksi effervescent dalam air yang sebagian akan larut membentuk asam karbonat yang akan mengurai ion $\mathrm{H}^{+}$ dalam larutan sehingga menyebabkan keasaman dalam larutan dan berakibat nilai $\mathrm{pH}$ menjadi lebih rendah.

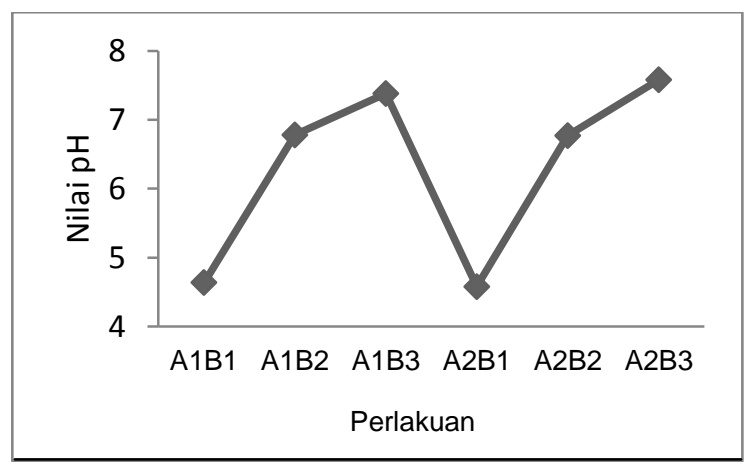

Ket.: A1B1 (as. sitrat : tartarat $(1: 1,5)$ dan asam : basa (25\%:20\%)), A1B2 (as. sitrat : tartarat $(1: 1,5)$ dan asam : basa (20\%:25\%)), A1B3 (as. sitrat : tartarat (1:1,5) dan asam : basa (15\%:30\%)), A2B1 (as. sitrat : tartarat (1:2) dan asam : basa (25\%:20\%)), A2B2 (as. sitrat : tartarat (1:2) dan asam : basa (20\%:25\%)), A2B3 (as. sitrat : tartarat (1:2) dan asam : basa (15\%:30\%)).

Gambar 1. Nilai pH serbuk effervescent

Kailaku et al. (2012) menyatakan bahwa produk effervescent adalah produk minuman yang mengandung senyawa asam basa, pada saat kedua senyawa tersebut bereaksi karena adanya air, maka kedalam larutan akan terjadi pelepasan kedua senyawa tersebut, dimana rasa asam ditandai dengan $\mathrm{pH}$ larutan yang rendah. Demikian juga dengan pelepasan senyawa basa lemah dari natrium bikarbonat yang ditandai dengan keluarnya gelembung-gelembung udara dari basa yang bereaksi dengan asam.

Minuman effervescent memiliki ciri khas asam. Hal ini karena adanya penambahan asam sitrat dan asam tartarat yang digunakan sebagai kombinasi dengan Na-bikarbonat untuk membentuk efek soda. Nilai rata-rata uji kadar $\mathrm{pH}$ berkisar antara 4,44-7,58. Kisaran $\mathrm{pH}$ tersebut merupakan $\mathrm{pH}$ asam sampai netral. Sesuai dengan karakteristik minuman effervescent yang bersifat asam karena adanya penambahan asam sitrat dan asam tartarat. Sebetulnya $\mathrm{pH}$ yang 
sedikit asam ini dapat memberikan rasa yang lebih segar pada sediaan effervescent (Rienoviar et al., 2011).

\section{Analisis Kadar air Serbuk Effervescent}

Jumlah air merupakan hal yang dapat mempengaruhi terjadinya reaksi kimia dini dari komponen asam dan basa yang terdapat dalam komposisi effervescent. Kadar air granul juga dapat mempengaruhi proses pencetakan tablet, jika granul terlalu lembab maka pada saat pencetakan granul akan melekat pada dinding alat cetak, sedangkan jika granul terlalu kering maka tablet akan rapuh. Hasil uji kandungan lembab granula serbuk effervescent dapat dilihat pada Gambar 2.

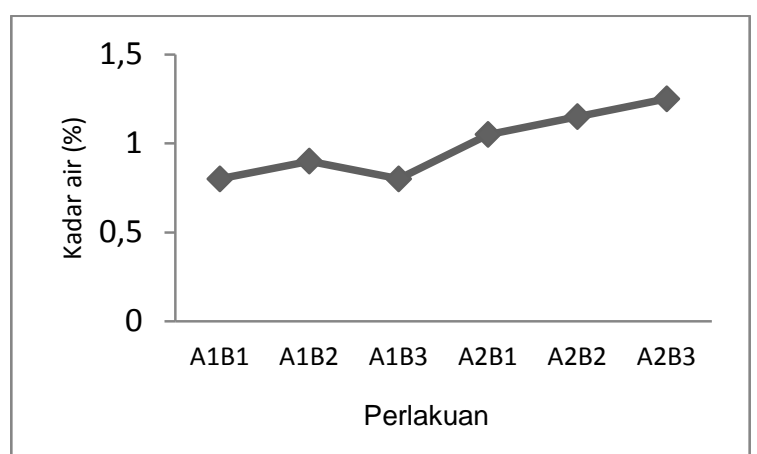

Ket.: A1B1 (as. sitrat : tartarat $(1: 1,5)$ dan asam : basa $(25 \%: 20 \%))$, A1B2 (as. sitrat : tartarat $(1: 1,5)$ dan asam : basa $(20 \%: 25 \%))$, A1B3 (as. sitrat : tartarat $(1: 1,5)$ dan asam : basa (15\%:30\%)), A2B1 (as. sitrat : tartarat (1:2) dan asam : basa (25\%:20\%)), A2B2 (as. sitrat : tartarat (1:2) dan asam : basa (20\%:25\%)), A2B3 (as. sitrat : tartarat (1:2) dan asam : basa (15\%:30\%)).

Gambar 2. Kadar air serbuk effervescent

Hasil evaluasi kadar air serbuk effervescent pada Tabel 2, berkisar antara 0,8\%-1,25\%, dimana perlakuan perbandingan asam basa berpengaruh terhadap hasil kandungan lembab serbuk yaitu semakin rendah (A2B1, A2B2 dan A2B3). Hasil tersebut masih memenuhi kriteria penerimaan, untuk serbuk yang akan dikemas dengan sachet kadar air maksimal $3 \%$, lebih kecil lebih baik, tetapi bila untuk dicetak serbuk effervescent tersebut tidak memenuhi kriteria. Menurut Lachman et al. (1989) dalam Rienoviar et al. (2011), menyatakan bahwa kriteria penerimaan kadar air untuk granul yang diteruskan untuk dicetak berada pada kisaran $2-5 \%$.

\section{Analisis Waktu Alir Serbuk Effervescent Coklat}

Hasil uji waktu alir serbuk effervescent coklat (Gambar 3) dapat dilihat bahwa untuk produk effervescent kisaran antara 4,85-10,21 g/dtk, termasuk kedalam kategori mudah mengalir sampai bebas mengalir (Aulton, 1988 dalam Rienoviar et al., 2011). Hasil analisis daya alir dapat dilihat pada Gambar 3.

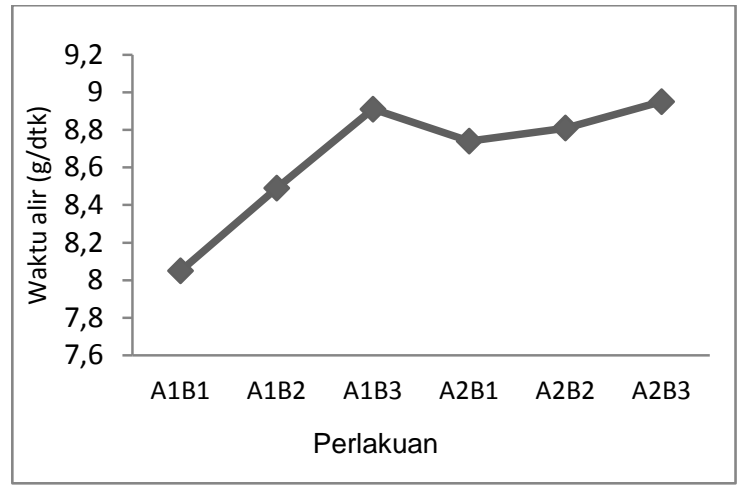

Ket.: A1B1 (as. sitrat : tartarat $(1: 1,5)$ dan asam : basa (25\%:20\%)), A1B2 (as. sitrat : tartarat $(1: 1,5)$ dan asam : basa (20\%:25\%)), A1B3 (as. sitrat : tartarat $(1: 1,5)$ dan asam : basa (15\%:30\%)), A2B1 (as. sitrat : tartarat (1:2) dan asam : basa (25\%:20\%)), A2B2 (as. sitrat : tartarat (1:2) dan asam : basa (20\%:25\%)), A2B3 (as. sitrat : tartarat (1:2) dan asam : basa (15\%:30\%)).

Gambar 3. Waktu Alir serbuk effervescent

Dari hasil analisis waktu alir serbuk effervescent coklat dapat dilihat bahwa perlakuan perbandingan jenis asam dan perlakuan perbandingan pemakaian jumlah asam dan basa berpengaruh terhadap waktu alir serbuk effervescent yang dihasilkan, dimana dengan meningkatnya perbandingan asam dan perubahan perbandingan jumlah asam basa menyebabkan semakin meningkatnya nilai waktu alir dari serbuk effervescent. Menurut Burhan et al., (2012) semakin banyak penggunaan natrium bikarbonat akan semakin meningkatkan kandungan air granul.

Waktu alir adalah waktu yang diperlukan untuk mengalir dari sejumlah granul melalui lubang corong, yang diukur adalah sejumlah zat yang mengalir dalam suatu waktu tertentu. Waktu alir dipengaruhi oleh bentuk, ukuran, porositas, densitas, gaya, elektrostatik, dan gaya gesek partikel serta kondisi percobaan (Prasetyo et al., 2015). 


\section{Analisis Nilai Waktu Larut Serbuk Effervescent Coklat}

Berdasarkan hasil pengujian waktu larut serbuk effervescent dari coklat produk effervescent yang dibuat tidak memenuhi peryaratan resmi yang tertera dalam British Pharmacopea (2001), dimana waktu larut tablet effervescent adalah kurang dari 5 menit pada suhu $15-25^{\circ} \mathrm{C}$. Hasil uji waktu larut dapat dilihat pada Gambar 4.

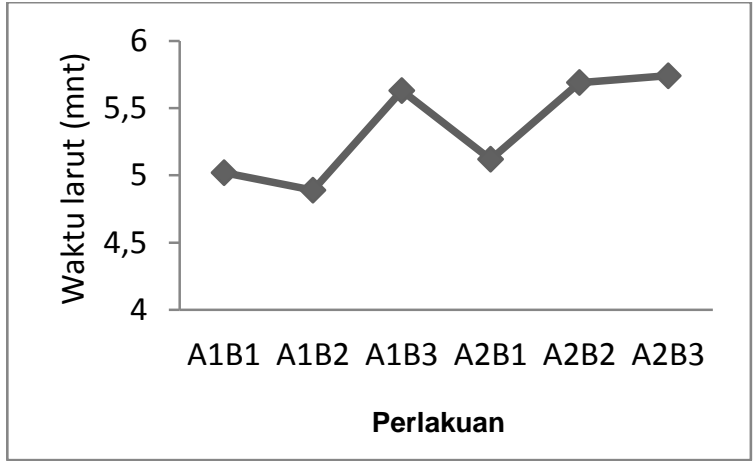

Ket.: A1B1 (as. sitrat : tartarat $(1: 1,5)$ dan asam : basa $(25 \%: 20 \%))$, A1B2 (as. sitrat : tartarat $(1: 1,5)$ dan asam : basa $(20 \%: 25 \%))$, A1B3 (as. sitrat : tartarat $(1: 1,5)$ dan asam : basa (15\%:30\%)), A2B1 (as. sitrat : tartarat (1:2) dan asam : basa (25\%:20\%)), A2B2 (as. sitrat : tartarat (1:2) dan asam : basa $(20 \%: 25 \%)$ ), A2B3 (as. sitrat : tartarat (1:2) dan asam : basa (15\%:30\%)).

Gambar 4.Waktu larut serbuk effervescent

Tidak terpenuhinya syarat untuk produk kemungkinan disebabkan perbandingan asam basa dan komponen penyusun dari serbuk itu sendiri. Seperti dapat dilihat bahwa perlakuan variasi asam dan basa juga terdapat variasi perlakuan perbandingan antara asam sitrat dan asam tartarat, dimana perbandingan antara asam basa yang hampir setara (A1B2) akan memberikan waktu larut yang lebih cepat dibandingkan dengan perbandingan asam basa yang tidak setara atau yang selisihnya lebih jauh (A2B3).

Waktu larut adalah waktu yang dibutuhkan oleh produk untuk larut secara cepat. Kelarutan sangat dipengaruhi oleh adanya bahan aktif dalam formula yang berasal dari tanaman, seperti ekstrakekstrak yang memiliki sifat sukar larut dalam air. Oleh karena itu perlu ditambahkan zat pengemulsi agar ekstraknya terdispersi sempurna dalam larutan, dan ekstrak tersebut tidak mudah mengendap pada dasar larutan (Kailaku et al., 2012).

Kelarutan merupakan sifat bahan baku yang paling penting dalam effervescent, jika komponen tidak larut, reaksi effervescent tidak akan terjadi dan tidak akan terdisintegrasi secara cepat. Kecepatan kelarutan lebih penting dari kelarutan karena zat yang terlarut lambat dapat merintangi desintegrasi serbuk/tablet dan larut lambat menghasilkan residu yang tidak disukai setelah tablet/serbuk terdisintegrasi. Berdasarkan data diatas maka, semua perlakuan tidak memenuhi persyaratan dari segi waktu larut. Hal itu disebabkan karena sifat fisik dari komponen bubuk coklat yang tidak larut, sehingga menghambat integrasi serbuk sewaktu dilarutkan dalam air (Rienoviar et al., 2011).

Waktu larut juga dipengaruhi oleh kemampuan bahan menyerap air atau lebih dikenal dengan indeks penyerapan air. Indeks penyerapan air adalah banyaknya air yang dapat diserap oleh padatan. Reaksi effervescing terjadi ketika asam basa bereaksi dengan air. Reaksi dari granula cokelat dengan asam sitrat akan menghasilkan Ca-sitrat, $\mathrm{H}_{2} \mathrm{O}$, dan $\mathrm{CO}_{2}$ (Ansel, 1989). Sehingga semakin banyak air yang terserap dan kontak dengan bahan, maka reaksi effervescing akan berjalan optimal. Hal ini dipengaruhi karena terjadi pembetukan ikatan hidrogen dengan molekul air sehingga mudah menyerap molekul air. Alasan ini juga bisa menyebabkan waktu larut serbuk effervescent coklat masih tinggi (Supriyanto et al., 2013).

Kemungkinan lain adalah coklat bubuk yang digunakan masih memiliki kadar lemak yang tinggi. Adanya kandungan lemak dalam bahan inilah yang akan menghambat air untuk bisa terserap dan kontak dengan bahan. $\mathrm{Hal}$ ini dikarenakan sifat lemak yang tidak larut dalam air (Sudarmadji, 2007). Ini sebabnya air menjadi sukar kontak dengan bahan penyusun tablet sehingga reaksi effervescing berjalan kurang optimal. Ini menyebabkan waktu yang dibutuhkan serbuk untuk bisa larut dan hancur sempurna di dalam air juga akan semakin lama (Supriyanto et al., 2013). 
Uji Sensoris Serbuk effervescent Coklat

Untuk penilaian aroma pada semua perlakuan mendapat skor agak suka, karena masih memilki aroma coklat. Hasil uji sensoris untuk serbuk effervescent coklat dapat dilihat pada Gambar 5 .

Pada uji sensoris yang dilakukan terhadap serbuk effervescent coklat untuk kategori warna pada semua perlakuan menghasilkan warna agak cerah sampai kurang cerah. Hal ini disebabkan karena serbuk mempunyai waktu larut yang lama sehingga tidak semua serbuk terlarut sempurna dan mempengaruhi warna dari minuman.

Sedangkan untuk nilai rasa pada semua perlakuan berkisar dari tidak suka sampai kurang suka. Hal ini disebabkan rasa minuman effervescent coklat yang cenderung asam dan semakin asam sesuai dengan perlakuan perbandingan asam basa sementara komposisi jumlah coklat bubuk yang digunakan sama untuk semua perlakuan. Supriyanto et al., (2013) menyatakan bahwa semakin banyak komposisi cokelat bubuk tentunya akan semakin memperkuat rasa cokelat pada seduhan, sehingga panelis akan semakin menyukai. Hasil secara keseluruhan menunjukkan bahwa proporsi jumlah asam yang sedikit lebih banyak bila dibandingkan dengan jumlah basa, lebih disukai oleh panelis.

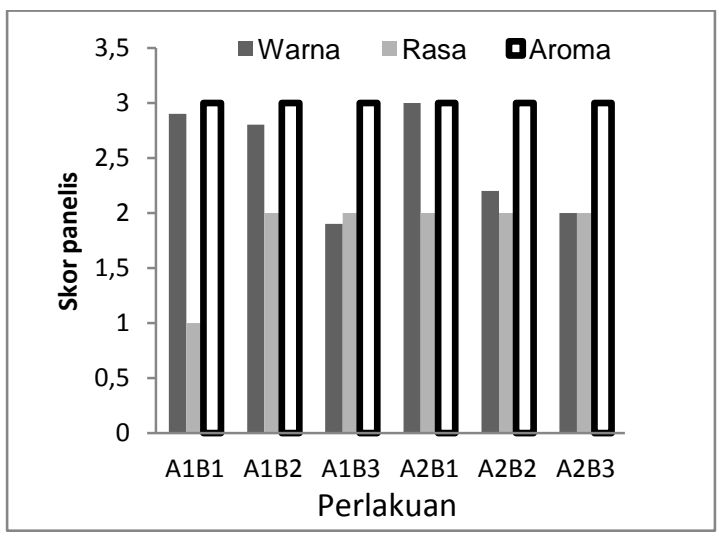

Ket.: A1B1 (as. sitrat : tartarat $(1: 1,5)$ dan asam : basa (25\%:20\%)), A1B2 (as. sitrat : tartarat $(1: 1,5)$ dan asam : basa $(20 \%: 25 \%))$, A1B3 (as. sitrat : tartarat $(1: 1,5)$ dan asam : basa (15\%:30\%)), A2B1 (as. sitrat : tartarat (1:2) dan asam : basa (25\%:20\%)), A2B2 (as. sitrat : tartarat (1:2) dan asam : basa (20\%:25\%)), A2B3 (as. sitrat : tartarat (1:2) dan asam : basa (15\%:30\%)).

Gambar 5. Hasil uji sensoris serbuk Effervescent coklat
KESIMPULAN

Coklat bubuk dapat dibuat produk minuman effervescent coklat. Serbuk Effervescent dibuat dengan perlakuan perbandingan asam sitrat dan asam tartarat 1:1,5 dan 1:2 dan perbandingan komponen asam dan basa yakni 15\%:10\%, 10\%:15\% dan 5\%:20\% masih memenuhi kriteria dalam evaluasi untuk serbuk, tapi tidak memenuhi untuk evaluasi bila diteruskan kedalam bentuk tablet effervescent. Pada pembuatan serbuk effervescent cokelat perlakuan optimal pada perbandingan asam sitrat dan tartarat 1:2 dan perbandingan komponen asam dan basa 20\%:25\% (A2B2), yang mempunyai nilai $\mathrm{pH}$ 6,77, kandungan lembab $1,3 \%$, waktu alir $6,19 \mathrm{~g} / \mathrm{dtk}$, dan waktu larut pada suhu $35^{\circ} \mathrm{C}$ selama 5,69 detik, dengan uji sensoris warna kurang suka, aroma agak suka, dan rasa kurang suka.

\section{UCAPAN TERIMA KASIH}

Penulis mengucapkan terima kasih kepada Elya Rovina dan Titi Putri Ningsih atas kerjasama dan bantuannya dalam kegiatan penelitian ini.

\section{DAFTAR PUSTAKA}

Ansel, H. C. 1989. Pengantar bentuk sediaan farmasi. UI Press, Jakarta.

Anam, C, Kawiji, dan Dwi Rizki, S. 2013. Kajian karakteristik fisik dan sensori serta aktivitas antioksidan dari granul effervescent buah beet (beta vulgaris) dengan perbedaan metode granulasi dan kombinasi sumber asam. Jurnal Teknosains Pangan, 2(2): 21-27.

Aulton, M.E. 1988. Pharnacutics : The science of dosage from design. Edinburg: Churvill livingstone.

BSN. 2013. SNI 01-3747-2013. Coklat bubuk. Pusat Standarisasi. Jakarta.

BSN. 2010. SNI 01-3140-2010. Gula pasir. Pusat Standarisasi. Jakarta.

British Pharmacopea. Jilid 2. 2001. Effervescent tablets. London : The Stationery Office. Hal. 1812. 
Burhan, L., Yoemlan, P.V.Y, dan Supriati, H.S. 2012. Formulasi sediaan granul effervescent sari buah sirsak (Annona muricata L). UNSRAT, STIKES Muhammadiyah. Manado.

Direktorat Jendral Perkebunan. Kementerian Pertanian Indonesia. 2013. Kebijakan pengembangan agribisnis kakao. Disampaikan pada Workshop Pembangunan Model Desa Kakao, Yogyakarta.

Kailaku, S.I., Sumangat, Jayeng, dan Hermani. 2012. Formulasi granul effervescent kaya antioksidan dari ekstrak daun gambir. Jurnal Pasca Panen, 9(1): 27-34. Balai Besar Litbang Pascapanen Pertanian.

Lachman, L. H., Lieberman, dan J. Kanig L. 1989. Teori dan praktek farmasi industri. Edisi ke-3. UI Press, Jakarta.

Lee, R. E. 2010. Effervescent Tablets: Key facts about a unique, effective dossage form. CSC Publishing, Tablets and Capcules.

Lieberman, H. A. L., Lachman dan J. B. Schwartz. 1989. Pharmaceutical dosage form-tablet. Vol. 1. Marcel Dekker Inc., New York.

Linberg, N. $1992 . \quad$ Effervescent pharmaceuticals dalam encyclopedia of pharmaceutical technology ed swarbick vol. 5 Marcell Dekker Inc., New York.
Novidiyanto dan Setyowati. 2008. Formulasi serbuk effervescent sari wortel. Jurnal Agritech, 28(4): 150157.

Prasetyo, G., Zaky, Z., Itsna, Etikasari, M., Farid, W.R., Widyaningsih,T.D. 2015. Formulasi serbuk effervescent berbasis cincau hitam dengan penambahan daun pandan dan jahe merah. Jurnal Pangan dan Agroindustri, 3(1): 90-95.

Rienoviar, Novitasari, N., dan Prasetyorini. 2011. Aplikasi jambu biji merah (psidium guajava linn) pada pembuatan tablet effervescent. Jurnal Riset Industri, V(1): 49-62.

Sandrasari, D.A., dan Abidin, Z. 2012. Penentuan konsentrasi natrium bikarbonat dan asam sitrat pada pembuatan serbuk minuman anggur berkarbonasi (effervescent). Jurnal Tek. Ind. Pert. 21(2): 113-117.

Sudarmadji, S., Haryono, B., dan Suhardi. 2007. Analisa bahan makanan dan pertanian. Penerbit Liberty: Yogyakarta.

Supriyanto, Murdiati, A., Apprila, F. 2013. Kajian pembuatan effervescent cokelat pada berbagai variasi jumlah asam dan basa yang digunakan terhadap sifat fisik, kimia dan sensorisnya. Prosiding Seminar Nasional Patpi. ISBN 978-602-9030-49-5. Jember. 